ñSynthesis of lipid-oligonucleotide conjugates for RNA interference studiesò Grijalvo, S., Ocampo, S. M., Perales, J. C., Eritja, R. Chem. Biodivers., 8(2), 287-299 (2011). doi: $10.1002 / c b d v .201000274$

\title{
Synthesis of lipid-oligonucleotide conjugates for RNA interference studies.
}

by Santiago Grijalvo ${ }^{a}$ ), Sandra M. Ocampo ${ }^{a}$ ), José C. Perales ${ }^{b}$ ) and Ramon Eritja $\left.^{*}, \mathrm{a}\right)$.

$\left.{ }^{a}\right)$ Institute for Research in Biomedicine, IQAC-CSIC, CIBER-BBN Networking Centre on Bioengineering, Biomaterials and Nanomedicine, Edifici Helix, Baldiri Reixac 10, E-08028 Barcelona, Spain. (phone: +34(93)4039942; fax: +34(93)2045904; e-mail:

$$
\text { recgma@cid.csic.es) }
$$

b) Biophysics Unit, Department of Physiological Sciences II, Universitat de Barcelona; Feixa Llarga s/n, E-08907 LôHospitalet del Llobregat, Barcelona, Spain. 


\begin{abstract}
The synthesis of RNA molecules carrying lipids at their 3ôtermini and 5ôtermini is reported. These conjugates were fully characterized by MALDI-TOF mass spectrometry and HPLC chromatography. The ability of these conjugates to silence gene expression was evaluated in the inhibition of the tumor necrosis factor. All the lipid-siRNA derivatives were compatible with RNA interference machinery if transfected with oligofectamine. In the absence of a transfection agent some lipid-siRNA derivatives can exert a slight reduction of gene expression.
\end{abstract}

Introduction.- Many years ago the use of modified nucleic acids to inhibit gene expression by blocking translation and transcription or by stimulating the degradation of a particular messenger RNA (mRNA) became a promising approach in therapy. This process uses antisense technology [1-3] and, more recently, RNA interference (RNAi) [4]. Although both strategies inhibit the same stage of translation of a gene to a protein, their mechanisms are different. In the case of antisense technology, synthetic oligonucleotides are designed to selectively bind to the complementary mRNA transcript of a targeted gene thereby inhibiting mRNA translation to the corresponding protein [5]. In contrast the RNAi approach uses short double-stranded RNA (dsRNA) molecules to switch genes off. Components of the RNAi machinery specifically recognize the short interfering duplex RNAs (siRNA) and incorporate the guide RNA strand into a protein complex named the RNA-induced silencing complex (RISC). The 
complex formed by the guide RNA strand and RISC catalyzes the degradation of a specific mRNA, thereby repressing the synthesis of a specific protein [6-7]. However, the use of oligonucleotides in both therapies is inefficient, since they are rapidly degrated by exonucleases and endonucleases in physiological conditions, and also because of their poor cellular uptake, which is primarily due to their relatively large molecular weight and their polyanionic nature. The lack of solutions to these two problems (especially in the case of cellular uptake), have caused a bottleneck in the development of nucleic acids in potential therapeutics [8].

In order to enhance the stability of oligonucleotides to nuclease degradation and increase cellular uptake a major research effort is being made to design and synthesize modified nucleic acids with similar hybridization properties but improved biological properties [9-11]. The synthesis of modified nucleic acids such as phosphorothioate [12], methyl phosphonate [13] and phosphoramidate oligonucleotides [14] locked nucleic acids [15] or peptide nucleic acids [16] has efficiently improved the stability of oligonucleotides in serum. On the issue of delivery progress has been made in the development of new non-viral carriers such as polymers [17], lipids [18], cellpenetrating peptides [19] or nanoparticles [20] for oligonucleotide delivery. However, despite considerable research, efficiency and specificity results are still not satisfactory in many cases. To date, most of the strategies for improving cellular uptake use carriers that can be covalently linked to ODNs using the post-synthetic conjugation [21-24] method or through the preparation of complexes (lipoplexes, polyplexes) [25-28]. The formation of these complexes is due to the existence of electronic interactions between polyanionic nucleic acids and the positively charged nature of the designed carrier. In particular, the conjugation of lipids to siRNA, such as cholesterol and fatty acids, produces molecules with improved inhibitory properties [29-32]. 
As part of our ongoing interest in gene-silencing methods [33-34] and in finding new carriers to improve inhibition and cellular uptake, we now propose a simple strategy in which several lipid tails are covalently linked to oligonucleotides at their $3 \hat{o}$ end (using controlled pore glass (CPG) supports) or at 5ôend (phosphoramidite chemistry) (Figure 1). The target lipid molecules are based on the lipids that are used to formulate the stable nucleic acid-lipid particles (SNALP) [35-36] for the systemic administration of siRNA [37-38]. We studied the silencing properties of the conjugates carrying the lipid modification in the passenger strand of the siRNA. Our target for RNAi studies is the tumor necrosis factor (TNF-Ŭ) gene. The protein is involved in several biological processes such as apoptosis, inflammation and immunity and it has been implicated in the pathogenesis of many human diseases. The inhibition of this cytokine is of particular relevance for the development of anti-inflammatory drugs [24].

Figure 1

Results and Discussion.- 1. Synthesis of lipid derivatives. We considered the use of a glycerol backbone based structure to be a suitable scaffold for introducing our chemical modifications, covalently linked to oligonucleotides at their 3ôend. This strategy was successfully used to introduce the 1-O-hexyldecylglycerol unit into antisense DNA [39]. The synthesis is outlined in Scheme 1. To prepare oligonucleotides carrying lipids $\mathrm{C}_{14}$ and $\mathrm{C}_{18}$ at the 3 ôposition, controlled pore glass (CPG) supports were functionalized by reaction of the suitable trityl-lipid derivatives 4 or 9 with aminofunctionalized CPG prior to DNA/RNA synthesis. To synthesize $\mathbf{4}$, the alkylation reaction between commercially available solketal $\mathbf{1}$ and 1-bromotetradecane with sodium hydride $(60 \%)$ in the presence of toluene was carried out to yield the respective alkylated compound 2. Acetonide hydrolysis $(p \mathrm{TsOH}, \mathrm{MeOH})$ yielded the expected diol 
3, which was selectively protected using the 4-monomethoxy trityl (MMTr) group. This reaction provided the desired trityl-protected alcohol $\mathbf{4}$ at a high yield. We used a similar synthetic route for the synthesis of trityl alcohol 9. Mesylate 6 was used in the alkylation reaction instead of a bromo derivative. Then, compounds $\mathbf{7 , 8}$ and 9 were prepared in good yields and were fully characterized. Finally, with the two synthesized trityl compounds 4 and 9 on hand, we coupled them to CPG supports using the succinyl linker described in the literature [40-41]. CPG functionalization yielded glass beads that were loaded with our proposed lipids containing $5(15 \mu \mathrm{mol} / \mathrm{g})$ and $10(16 \mu \mathrm{mol} / \mathrm{g})$, respectively. To introduce lipids $\mathrm{C}_{28}$ and $\mathrm{C}_{14} \mathrm{~N}$ at the 5ôposition, we used the phosphoramidite approach (Scheme 2). For the synthesis of lipid phosphoramidite 15; the selective protection of commercially available primary alcohol $\mathbf{1 1}$ with trityl chloride was carried out according to the literature [42]. Then, protected alcohol 12 was subjected to an alkylation reaction using 1-bromotetradecane in the presence of THF, which resulted in alkylated-trityl derivative $\mathbf{1 3}$ at a high yield. Subsequently, trityl deprotection under acid conditions (DCM:TFA 20\%) easily produced alcohol 14 which was transformed into the desired phosphoramidite 15. This was then directly used for the synthesis of oligonucleotides without further purification.

\section{Scheme 1}

Lipophosphoramidite 19 was synthesized by a double alkylation reaction of commercially available protected triol $\mathbf{1 6}$ and 1-bromotetradecane, according to the literature [36]. The removal of the allyl group of compound 17 with $\mathrm{Pd}\left[(\mathrm{PhP})_{3}\right]_{4}$ in the presence of THF yielded the desired alcohol 18, which was subsequently transformed into its phosphoramidite derivative 19. As in the previous case, phosphoramidite 19 was used for DNA / RNA synthesis without further purification.

Scheme 2 
2. Synthesis of oligodeoxynucleotide-lipid conjugates. Solid supports and phosphoramidites that have been previously described were used for the preparation of oligonucleotides carrying lipids at the 3ô or 5ôends. We selected the selfcomplementary oligodeoxynucleotide sequence 5ôd(CGCGAATTCGCG)-3ôknown as the Dickerson-Drew dodecamer, as a model compound. Oligonucleotide sequences were assembled on a DNA synthesizer using standard protocols. After the assembly of the desired DNA sequence, supports were treated with concentrated ammonia at $55^{\circ} \mathrm{C}$ for a minimum of $6 \mathrm{hrs}$ to yield oligonucleotides $\mathbf{2 0 - 2 3}$ carrying lipid molecules at the $3 \hat{o}$ or 5 ôends. In all cases a major peak was obtained that had the expected molecular weight as determined by MALDI-TOF mass analysis (experimental section). This indicates that the oligonucleotide-lipid conjugates are stable to oligonucleotide synthesis conditions.

2. Lipid-siRNA conjugates. Next the synthesis of lipid conjugates of RNA was studied. We selected a previously described siRNA duplex to inhibit the expression of the TNF- $\alpha$ gene [43]. These siRNA are being studied as potential anti-inflammatory drugs. RNA conjugates of passenger strands carrying lipids at the $3 \hat{\Theta}$ and $5 \hat{o} e n d$ were prepared (Table 1). A siRNA duplex carrying a cholesterol molecule at the 3ôend of the passenger strand was also prepared for comparison purposes. Finally, RNA conjugates

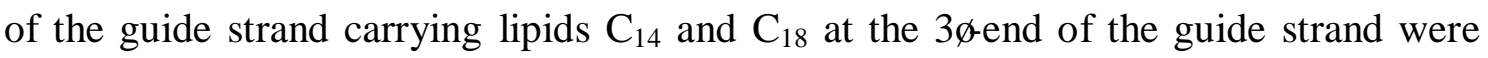
prepared (Table 1). Syntheses were carried out using standard RNA synthesis protocols and RNA monomers carrying the tert-butyldimethylsilyl (TBDMS) group in the $2 \hat{\Theta}$ position. RNA conjugates carrying lipids at the 3 ôposition were purified using DMT-on protocols whereas RNA conjugates carrying lipids at the 5ôposition were purified 
according to DMT-off protocols. All modified conjugates were purified by semipreparative HPLC chromatography. In all cases we obtained a major peak that was isolated and characterized by MALDI- TOF mass spectrometry (see Table 1). All conjugates were annealed with equimolar amounts of the unmodified guide strands and purified from EtOH precipitation (Table 1).

Table 1

We examined the effect of the lipids on siRNA duplex stability. The thermal stability of the modified and unmodified duplexes was measured in $100 \mathrm{mM}$ potassium acetate, $2 \mathrm{mM}$ magnesium acetate, and $30 \mathrm{mM}$ HEPES-KOH at $\mathrm{pH} 7.4$ (Table 2). The melting curves of the duplexes were virtually identical $\left(83.9^{\circ} \mathrm{C}, 83.6^{\circ} \mathrm{C}, 84.3^{\circ} \mathrm{C}\right.$; for siRNA-3, siRNA-5 and siRNA-6, respectively) compared to the siRNA-1 wild type $\left(83.5^{\circ} \mathrm{C}\right)$, except for siRNA-4, which stabilized slightly when hybridized to its complement $\left(86.9^{\circ} \mathrm{C}\right.$, with $\left.q \mathrm{qT}_{\mathrm{m}}=3.4^{\circ} \mathrm{C}\right)$. This was probably due to the presence of $2 \hat{\mathrm{o}}$ OMe groups in the pyrimidines of the RNA molecule [44] (Table 2). These results indicate that the presence of lipid groups at the 3 and 5ôposition of the siRNA molecule does not affect their ability to form stable duplexes.

\section{Figure 2}

Next, we studied the TNF-Ǔ inhibitory properties of the lipid-modified siRNA duplexes [40] using two different series of experiments. In the first case, siRNA transfection was carried out using commercially available cationic lipid (oligofectamine). To this end, HeLa cells were first transfected with plasmid expressing murine TNF-Ǔ using lipofectin. One hour later, unmodified siRNA-1 or lipid-modified siRNA conjugates in the passenger strand (siRNA-2, siRNA-3, siRNA-4, siRNA-5, siRNA-6 and siRNA-7, respectively at $50 \mathrm{nM}$ ) as well as the scrambled sequence Scr were co-transfected using Oligofectamine. Cells were analyzed using an enzyme-linked 
immunoabsorbent assay (ELISA) after twenty four hours of transfection. Inhibition results are depicted on Figure 2. Unmodified and modified siRNA conjugates at the $3 \hat{\vartheta}$ position (siRNA-2, siRNA-3, siRNA-4 and siRNA-5) showed 90-95\% inhibition of the TNF-Ǔproduction compared to the scrambled control Scr duplex. The inhibition results for the modified siRNA conjugates at the 5ôposition were somewhat lower $(80 \%$ and $60 \%$ for siRNA-6 and siRNA-7, respectively). Although we obtained better inhibition results for modified siRNA conjugates at the 3ôposition, in general, the introduction of the lipid modifications did not disrupt the RNAi machinery. After verifying the functionality of our modifications, we evaluated whether the presence of the lipid modifications in siRNA duplexes could improve the cellular uptake process. After transfecting HeLa cells with the murine TNF- $\alpha$ plasmid, the cells were treated with unmodified and modified siRNA conjugates (siRNA-1, siRNA-2, siRNA-3, siRNA-4, siRNA-5 and siRNA-6 at $100 \mathrm{nM}$ ) in the absence of a transfection agent (Figure 3). The inhibition activity of TNF-Ŭ is much lower in this case, due to the absence of Oligofectamine. However, some chemically modified siRNAs silenced the TNF-Ŭgene expression with promising inhibitory results $(19 \%, 17 \%$ and $38 \%$ for siRNA-5, siRNA6 and siRNA-7, respectively) compared to the scrambled siRNA duplex (siRNA 8). Surprisingly, the most active siRNA without a transfecting agent is the less active siRNA with oligofectamine. These results indicate that the most interesting siRNA derivative prepared in this work was the siRNA-7, which carries the $\mathrm{C}_{28}$ lipid at the $5 \hat{O}$ end.

Figure 3

The inhibitory properties of siRNA duplexes carrying lipids at the guide strand (siRNA-9, siRNA-10) were also analyzed (Figure 4). Lipid-modified (siRNA-9, siRNA-10) and unmodified siRNA (siRNA-1) against TNF- $\alpha$ produced an $80-90 \%$ 
inhibition of the production of TNF- $\alpha$ compared with the scrambled control siRNA duplex (siRNA 8). These results indicate that the introduction of the lipid at the 3 ôend of either the guide or the passenger strand of an RNA duplex does not affect the inhibitory properties of the resulting siRNA duplex in HeLa cells.

Figure 4

\section{Conclusions.}

In summary, we have reported an efficient strategy for introducing novel lipid moieties

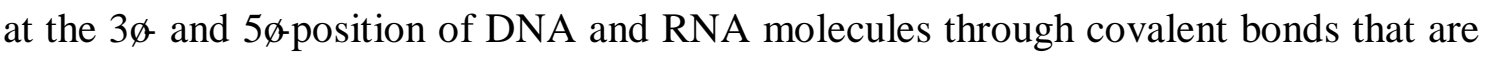
stable to oligonucleotide synthesis conditions. The effect of these modifications on the cellular activity does not interfere with the RNAi machinery. In the presence of a transfection agent, we observed better RNAi inhibitory properties with siRNA conjugates carrying lipids at the 3ôtermini. However, in the absence of transfection agent, we observed better cellular uptake when the lipid $C_{28}$ was attached at the $5 \hat{o}$ position of the passenger strand. These promising results will be followed up with more detailed cellular uptake studies using these conjugates as well as the use of non-viral carriers to improve gene delivery.

Acknowledgement. This study was supported by the Spanish Ministry of Education (grant BFU2007-63287 and CTQ2010-20541), the Generalitat de Catalunya (2009/SGR/208) and CIBER-BBN (VI National R\&D\&i Plan 2008-2011, Iniciativa Ingenio 2010, Consolider Program, CIBER Actions, Instituto de Salud Carlos III with assistance from the European Regional Development Fund.

\section{Experimental Part}


Materials and Methods. All reactions were carried out under argon positive pressure in anhydrous solvents. Commercially available reagents and anhydrous solvents were used without further purification. Solvents were distilled prior to use and dried using standard methods. Analytical samples were homogeneous, as confirmed by TLC, and yielded spectroscopic results that were consistent with the structures assigned. Chemical shifts are reported in parts per million (ppm) relative to the singlet at $\breve{\mathrm{u}}=7.24 \mathrm{ppm}$ of $\mathrm{CHCl}_{3}$ for ${ }^{1} \mathrm{H}$ NMR and to the centre line of the triplet at $\breve{\mathrm{u}}=77.0 \mathrm{ppm}$ of $\mathrm{CDCl}_{3}$ for ${ }^{13} \mathrm{C} \mathrm{NMR}$. IR spectra were measured on film and were recorded with a BOMEM MB-120. Thinlayer chromatography (TLC) was performed on silica gel (Alugram Sil G/UV). MALDI mass spectrometry was recorded on a Fisons VG Tofspec spectrometer and ESI mass spectra on a Fisons VG Platform II spectrometer. Oligonucleotide sequences were prepared using solid phase methodology on an Applied Biosystems Model 3400 DNA synthesizer. Oligoribonucleotides were purified by DMT-on protocols using reversedphase HPLC.

HPLC conditions. Conditions for semipreparative HPLC were as follows. HPLC solutions were solvent A: $5 \%$ acetonitrile $(\mathrm{ACN})$ in $100 \mathrm{mM}$ triethylammonium acetate (TEAA), $\mathrm{pH} 6.5$; and solvent $\mathrm{B}: 70 \% \mathrm{ACN}$ in $100 \mathrm{mM}$ triethylammonium acetate (pH 6.5). Column: PRP-1 (Hamilton) $250 \times 10 \mathrm{~mm}$. A flow rate $3 \mathrm{ml} / \mathrm{min}$ linear gradient from 15 to $100 \%$ in B (DMT-on) and 0 to $50 \%$ in B (DMT-off) was used with UV detection at $260 \mathrm{~nm}$.

General procedure for the alkylation reaction. Solketal 1 (100 mg, $0.757 \mathrm{mmol})$ and $60 \%$ sodium hydride $(\mathrm{NaH}, 60.4 \mathrm{mg}, 1.51 \mathrm{mmol}, 2.0 \mathrm{eq})$ were stirred in toluene (3.0 $\mathrm{mL}$ ) under argon for 20 minutes. The corresponding alkyl bromide $\mathrm{C}_{14}(420 \mathrm{mg}, 1.51$ mmol, $2.0 \mathrm{eq})$ or mesylate $\mathrm{C}_{18}(520 \mathrm{mg}, 1.51 \mathrm{mmol})$ was dissolved in toluene $(2.0 \mathrm{~mL})$ 
and added dropwise. The reaction was refluxed under argon overnight. It was then diluted with more toluene $(10 \mathrm{~mL})$ and the reaction mixture was cooled in an ice bath while quenched via the slow addition of cold water. The mixture was washed with water $(5 \mathrm{~mL})$ and brine $(5 \mathrm{~mL})$, using ethanol to aid phase separation if necessary. The organic phase was dried over anhydrous sodium sulphate and evaporated. The crude product was purified by flash chromatography (Ch:AcOEt $0 \%$ to 3\%).

2,2-dimethyl-4-(tetradecyloxymethyl)-1,3-dioxolane, 2. Yield: 78\%; IR (film) 2925, 2854, 1462, 1379, 1370, $1117.4 \mathrm{~cm}^{-1} ;{ }^{1} \mathrm{H}-\mathrm{NMR}\left(400 \mathrm{MHz}, \mathrm{CDCl}_{3}\right) \breve{\mathrm{u}} 4.26(\mathrm{q}, J=6.0$ Hz, 1H), $4.05(\mathrm{dd}, J=8.2 \mathrm{~Hz}, 6.4 \mathrm{~Hz} ; 1 \mathrm{H}), 3.73(\mathrm{dd}, J=8.2 \mathrm{~Hz}, 6.4 \mathrm{~Hz} ; 1 \mathrm{H}), 3.51$ (m, 2H), $3.43(\mathrm{~m}, 2 \mathrm{H}), 1.60(\mathrm{~m}, 4 \mathrm{H}), 1.42(\mathrm{~s}, 3 \mathrm{H}), 1.36(\mathrm{~s}, 3 \mathrm{H}), 1.25(\mathrm{~m}, 20 \mathrm{H}), 0.88(\mathrm{t}, J=$ $6.6 \mathrm{~Hz}, 3 \mathrm{H}) ;{ }^{13} \mathrm{C}-\mathrm{NMR}\left(400 \mathrm{MHz}, \mathrm{CDCl}_{3}\right.$ ) ŭ 109.6, 74.9, 72.1, 72.0, 67.1, 32.1, 30.0, 29.9, 29.8, 29.8, 29.8, 29.8, 29.7, 29.6, 29.5, 26.9, 26.2, 25.6, 22.9, 14.3; HR ESI MS: $m / z$ calculated for $\mathrm{C}_{20} \mathrm{H}_{40} \mathrm{Na} \mathrm{O}_{3}\left(\mathrm{M}^{+}+23\right), 351.2870$, found $m / z$ 351.2862; calculated for $\mathrm{C}_{40} \mathrm{H}_{80} \mathrm{Na} \mathrm{O}_{6}\left(2 \mathrm{M}^{+}+23\right), 679.5847$, found $m / z, 679.5835$.

2,2-dimethyl-4-(((10Z,13Z)-octadeca-10,13-dienyloxy)methyl)-1,3-dioxolane, 7. Yield: 77\%; IR (film) 3008, 2986, 2926, 2856, 1457, 1379, 1369, 1214, 1120, $847 \mathrm{~cm}^{-1}$; ${ }^{1} \mathrm{H}-$ NMR (400 MHz, $\left.\mathrm{CDCl}_{3}\right)$ ŭ $5.34(\mathrm{~m}, 4 \mathrm{H}), 4.25(\mathrm{q}, J=5.8 \mathrm{~Hz}, 1 \mathrm{H}), 4.04(\mathrm{dd}, J=14.6$ $\mathrm{Hz}, 8.2 \mathrm{~Hz}, 1 \mathrm{H}), 3.71(\mathrm{dd}, J=14.6 \mathrm{~Hz}, 8.2 \mathrm{~Hz}, 1 \mathrm{H}), 3.45(\mathrm{~m}, 4 \mathrm{H}), 2.76(\mathrm{t}, J=5.8 \mathrm{~Hz}$, 2H), $2.00(\mathrm{~m}, 4 \mathrm{H}), 1.56(\mathrm{~m}, 2 \mathrm{H}), 1.41(\mathrm{~s}, 3 \mathrm{H}), 1.35(\mathrm{~s}, 3 \mathrm{H}), 1.29(\mathrm{~m}, 20 \mathrm{H}), 0.88(\mathrm{t}, J=$ $6.8 \mathrm{~Hz}, 3 \mathrm{H}) ;{ }^{13} \mathrm{C}-\mathrm{NMR}\left(400 \mathrm{MHz}, \mathrm{CDCl}_{3}\right)$ ŭ 132.1, 128.9, 110.0, 72.7, 72.1, 70.5, 64.5, $32.1,30.0,29.9,29.8,29.8,29.8,29.6,29.5,26.3,22.9,14.3$; HR ESI MS: $m / z$ calculated for $\mathrm{C}_{24} \mathrm{H}_{44} \mathrm{Na} \mathrm{O}_{3}\left(\mathrm{M}^{+}+23\right)$, 403.3183, found $\mathrm{m} / z$ 403.3176.

General procedure for the deprotection reaction. A solution of alkylated compound 2 (1.0 eq) and alkylated compound 7 (1.0 eq) along with $p$-toluenesulphonic acid monohydrate $(0.5 \mathrm{eq})$ in methanol $(5.0 \mathrm{~mL})$ was stirred at room temperature overnight. 
The solvent was evaporated and the residue was purified by flash chromatography, eluted with DCM:MeOH $0 \%$ to $2 \%$.

3-(tetradecyloxy)propane-1,2-diol, 3. Yield: 72\%; IR (film) 2980, 2850, 2390, $2387 \mathrm{~cm}^{-}$ ; ${ }^{1} \mathrm{H}-\mathrm{NMR}\left(400 \mathrm{MHz}, \mathrm{CDCl}_{3}\right)$ ŭ $3.87(\mathrm{~m}, 1 \mathrm{H}), 3.74(\mathrm{dd}, J=11.4 \mathrm{~Hz}, 3.9 \mathrm{~Hz}, 1 \mathrm{H}), 3.67$ $(\mathrm{dd}, J=11.4 \mathrm{~Hz}, 5.0 \mathrm{~Hz}, 1 \mathrm{H}), 3.54(\mathrm{~m}, 2 \mathrm{H}), 3.48(\mathrm{~m}, 2 \mathrm{H}), 1.60(\mathrm{~m}, 4 \mathrm{H}), 1.27(\mathrm{~m}, 20 \mathrm{H})$, $0.89(\mathrm{t}, J=6.8 \mathrm{~Hz}, 3 \mathrm{H}) ;{ }^{13} \mathrm{C}-\mathrm{NMR}\left(400 \mathrm{MHz}, \mathrm{CDCl}_{3}\right)$ ŭ 72.8, 72.0, 70.5, 64.5, 32.1, 30.0, 29.9, 29.8, 29.8, 29.8, 29.6, 29.5, 26.3, 22.9, 14.3; HR ESI MS: $m / z$ calculated for $\mathrm{C}_{17} \mathrm{H}_{36} \mathrm{Na} \mathrm{O}_{3}\left(\mathrm{M}^{+}+23\right), 311.2557$, found $\mathrm{m} / \mathrm{z}$ 311.2555.

3-((10Z,13Z)-octadeca-10,13-dienyloxy)propane-1,2-diol, 8. Yield: $70 \%$; IR (film) 3105, 2990, 2365, 1530, $1329 \mathrm{~cm}^{-1} ;{ }^{1} \mathrm{H}-\mathrm{NMR}\left(400 \mathrm{MHz}, \mathrm{CDCl}_{3}\right)$ ŭ $5.33(\mathrm{~m}, 4 \mathrm{H}), 3.83$ (m, 1H), $3.64(\mathrm{~m}, 2 \mathrm{H}), 3.47(\mathrm{~m}, 4 \mathrm{H}), 2.74(\mathrm{~m}, 2 \mathrm{H}), 2.01(\mathrm{~m}, 4 \mathrm{H}), 1.55(\mathrm{~m}, 2 \mathrm{H}), 1.27(\mathrm{~m}$, $18 \mathrm{H}), 0.86(\mathrm{t}, J=6.8 \mathrm{~Hz}, 3 \mathrm{H}) ;{ }^{13} \mathrm{C}-\mathrm{NMR}\left(400 \mathrm{MHz}, \mathrm{CDCl}_{3}\right)$ ŭ 130.4, 130.3, 130.2, $130.2,128.2,128.1,128.1,128.0,72.6,72.5,72.0,72.0,70.8,70.7,64.4,64.3,31.8$, $31.7,29.9,29.8,29.7,29.7,29.7,29.6,29.6,29.5,29.5,29.4,29.4,29.4,27.4,26.3$, 26.2, 25.8, 25.8, 22.8, 22.7, 14.3; HR ESI MS: $m / z$ calculated for $\mathrm{C}_{21} \mathrm{H}_{40} \mathrm{Na} \mathrm{O}_{3}\left(\mathrm{M}^{+}+\right.$ 23), 363.2698, found $\mathrm{m} / \mathrm{z} 363.2697$.

General procedure for protection with MMTr. Diols 3 or 8 (1.0 eq) were co-evaporated twice with pyridine and dissolved again in pyridine $(2 \mathrm{~mL})$. DMAP $(0.1 \mathrm{eq})$ and MMTr$\mathrm{Cl}$ (1.5 eq) were added at room temperature and the corresponding mixtures were stirred at $40^{\circ} \mathrm{C}$ overnight. The reaction was quenched by addition of $\mathrm{MeOH}(5 \mathrm{~mL})$. The crudes were concentrated in vacuo and the residues were purified by flash chromatography (DCM:MeOH:TEA 98:1:1).

1-((4-methoxyphenyl)diphenylmethoxy)-3-(tetradecyloxy)propan-2-ol,4. Yield: 80\%; IR (film) 3200, 1630, 1521, 1232, $990 \mathrm{~cm}^{-1} ;{ }^{1} \mathrm{H}-\mathrm{NMR}\left(400 \mathrm{MHz}, \mathrm{CDCl}_{3}\right)$ ŭ $7.37(\mathrm{~m}, 2 \mathrm{H})$, $7.23(\mathrm{~m}, 5 \mathrm{H}), 7.19(\mathrm{~m}, 5 \mathrm{H}), 6.77(\mathrm{~m}, 1 \mathrm{H}), 6.74(\mathrm{~m}, 1 \mathrm{H}), 3.86(\mathrm{~m}, 1 \mathrm{H}), 3.73(\mathrm{~s}, 3 \mathrm{H}), 3.46$ 
$(\mathrm{dd}, J=9.7 \mathrm{~Hz}, 4.2 \mathrm{~Hz}, 1 \mathrm{H}), 3.39(\mathrm{dd}, J=9.7 \mathrm{~Hz}, 6.4 \mathrm{~Hz}, 1 \mathrm{H}), 3.35(\mathrm{~m}, 2 \mathrm{H}), 3.11(\mathrm{~m}$, 2H), $2.34\left(\right.$ broad d, 1H), $1.47(\mathrm{~m}, 2 \mathrm{H}), 1.19(\mathrm{~m}, 22 \mathrm{H}), 0.81(\mathrm{t}, J=6.6 \mathrm{~Hz}, 3 \mathrm{H}) ;{ }^{13} \mathrm{C}-$ NMR $\left(400 \mathrm{MHz}, \mathrm{CDCl}_{3}\right)$ ŭ 158.9, 158.7, 150.0, 147.3, 144.6, 135.7, 130.5, 129.4, $128.7,128.6,128.1,128.0,128.0,127.3,127.1,123.9,113.4,113.3,86.5,81.9,72.2$, $71.8,70.1,64.7,55.4,55.4,32.1,30.0,29.9,29.8,29.8,29.8,29.7,29.5,26.3,22.9$, 14.3; HR ESI MS: $m / z$ calculated for $\mathrm{C}_{38} \mathrm{H}_{54} \mathrm{Na} \mathrm{O}_{5}\left(\mathrm{M}^{+}+23\right), 613.7623$, found $m / z$ 613.7622.

1-((4-methoxyphenyl)diphenylmethoxy)-3-((10Z,13Z)-octadeca-10,13-ienyloxy)propan2-ol, 9. Yield: 67\%; IR (film) 3300, 2980, 2732, 1600, 1475, 1200, $995 \mathrm{~cm}^{-1} ;{ }^{1} \mathrm{H}-\mathrm{NMR}$ $\left(400 \mathrm{MHz}, \mathrm{CDCl}_{3}\right) \breve{u} 7.57(\mathrm{~m}, 1 \mathrm{H}), 7.36(\mathrm{~m}, 2 \mathrm{H}), 7.20(\mathrm{~m}, 7 \mathrm{H}), 7.10(\mathrm{~d}, \mathrm{~J}=8.8 \mathrm{~Hz}$, 2H), $6.75(\mathrm{~d}, \mathrm{~J}=8.8 \mathrm{~Hz}, 2 \mathrm{H}), 5.29(\mathrm{~m}, 4 \mathrm{H}), 3.87(\mathrm{~m}, 1 \mathrm{H}), 3.70(\mathrm{~s}, 3 \mathrm{H}), 3.45(\mathrm{dd}, J=9.7$ Hz, 4.2 Hz, 1H), $3.37(\mathrm{~m}, 1 \mathrm{H}), 3.10(\mathrm{~m}, 2 \mathrm{H}), 3.01(\mathrm{~m}, 2 \mathrm{H}), 2.69(\mathrm{t}, J=6.5 \mathrm{~Hz}, 2 \mathrm{H})$, $2.42($ broad d, 1H), $1.96(\mathrm{~m}, 2 \mathrm{H}), 1.46(\mathrm{~m}, 2 \mathrm{H}), 1.20(\mathrm{~m}, 18 \mathrm{H}), 0.80(\mathrm{t}, J=6.7 \mathrm{~Hz}, 3 \mathrm{H})$; ${ }^{13} \mathrm{C}$-NMR (400 MHz, $\left.\mathrm{CDCl}_{3}\right)$ ŭ 158.8, 149.9, 147.4, 144.6, 139.5, 136.1, 130.5, 129.4, $128.6,128.1,128.0,128.0,127.3,127.1,123.9,113.4,86.5,81.9,72.3,71.8,70.1,64.7$, $55.4,31.7,29.9,29.9,29.8,29.7,29.6,29.5,27.5,27.4,26.3,25.8,22.8,14.3$; HR ESI MS: $m / z$ calculated for $\mathrm{C}_{42} \mathrm{H}_{58} \mathrm{Na} \mathrm{O}_{5}\left(\mathrm{M}^{+}+23\right), 665.8249$, found $m / z 665.8250$.

General procedure for functionalization of CPG solid supports, 5 and 10. MMTrprotected alcohols 4 or 9 along with DMAP (1.5 eq) and succinic anhydride (1.5 eq) were dissolved in dichloromethane $(1 \mathrm{~mL})$. Reactions were stirred overnight at room temperature. Dichloromethane was added $(5 \mathrm{~mL})$ and the organic layers were then washed with a $0.1 \mathrm{M} \mathrm{Na} \mathrm{NPO}_{4}$ solution. The resulting organic layers were dried on sodium sulphate and the solvent was evaporated. The residues were used in the next step without further purification. 2,2-Dithio-bis-(5-nitropyridine) $(0.1 \mathrm{mmol})$ dissolved in $400 \varepsilon \mathrm{L}$ of acetonitrile was mixed with a solution of the appropriate MMTr-protected 
compounds $(0.1 \mathrm{mmol})$ and DMAP $(0.1 \mathrm{mmol})$ in acetonitrile (500 عL). A solution of TPP (0.1) dissolved in acetonitrile (200 عL) was added to the respective clear solutions at room temperature. The mixtures were then vortexed for a few seconds and added to a syringe containing LCAA-CPG (500 mg, $0.05 \mathrm{mmol}$ amino groups). They were allowed to react for 2 hours at room temperature. The reactions were arrested by adding methanol (500 عL). The supports were then washed with methanol (3 x $10 \mathrm{ml})$, acetonitrile $(3 \times 10 \mathrm{~mL})$ and diethyl ether $(3 \times 10 \mathrm{~mL})$. The solid supports were dried in vacuo and then subjected to capping of the residual amino functionalities with a mixture of acetic anhydride/pyridine/tetrahydrofurane (500 $\varepsilon \mathrm{L})$ and 1-methylimidazole in tetrahydrofurane (500 عL). After 30 minutes, the resins were washed with methanol (3 x $10 \mathrm{~mL})$, acetonitrile $(3 \times 10 \mathrm{~mL})$ and diethyl ether $(3 \times 10 \mathrm{~mL})$. The solid supports 5 and 10 were dried first in the air and then under high vacuum. Loading (5a) $(\varepsilon \mathrm{mol} / \mathrm{g})=15$; loading $(\mathbf{1 0})(\varepsilon \mathrm{mol} / \mathrm{g})=16$.

N,N-dimethyl-2-(tetradecyloxy)-3-(trityloxy)propan-1-amine, 13. Protected alcohol 12 (300 mg, $0.830 \mathrm{mmol})$ and $60 \% \mathrm{NaH}(133 \mathrm{mg}, 3.32,4.0 \mathrm{eq})$ were suspended in anhydrous THF ( $4.5 \mathrm{~mL})$ and stirred for $15 \mathrm{~min}$ at room temperature. Alkyl bromide (575 mg, $2.1 \mathrm{mmol}, 2.0 \mathrm{eq}$ ) was added dropwise. The reaction was heated to reflux overnight. It was then cooled at $0^{\circ} \mathrm{C}$ and water $(1.5 \mathrm{~mL})$ was added carefully. The solvent was evaporated and the residue was dissolved in dichloromethane $(10 \mathrm{~mL})$, washing the organic layer with water $(2 \times 20 \mathrm{~mL})$ and brine $(2 \times 20 \mathrm{~mL})$. The organic layer was dried on sodium sulphate and the solvent was evaporated. Crude was purified by flash chromatography (Ch:TEA 99:1 $\rightarrow$ Ch:AcOEt:TEA 98:1:1).

Yield: 77\%; IR (film) 3059, 2924, 2853, 2818, 2766, 1490, 1449, 1074, $909 \mathrm{~cm}^{-1} ;{ }^{1} \mathrm{H}-$ NMR (400 MHz, $\left.\mathrm{CDCl}_{3}\right)$ ŭ $7.39(\mathrm{~m}, 4 \mathrm{H}), 7.19(\mathrm{~m}, 11 \mathrm{H}), 3.45(\mathrm{~m}, 1 \mathrm{H}), 3.38(\mathrm{~m}, 2 \mathrm{H})$, $3.08(\mathrm{~m}, 2 \mathrm{H}), 2.31(\mathrm{~s}, 6 \mathrm{H}), 1.49(\mathrm{~m}, 2 \mathrm{H}), 1.18(\mathrm{~m}, 22 \mathrm{H}), 0.81(\mathrm{t}, J=6.6 \mathrm{~Hz}, 3 \mathrm{H}) ;{ }^{13} \mathrm{C}-$ 
NMR (400 MHz, $\left.\mathrm{CDCl}_{3}\right)$ ŭ 144.4, 128.9, 127.9, 127.1, 86.7, 77.9, 70.7, 70.6, 64.9, 61.7, 60.2, 46.5, 45.7, 32.1, 30.4, 30.0, 29.9, 29.8, 29.6, 26.4, 22.9, 14.4; HR ESI MS: $m / z$ calculated for $\mathrm{C}_{38} \mathrm{H}_{56} \mathrm{NO}_{2}\left(\mathrm{M}^{+}+\mathrm{H}\right), 558.4306$, found $m / z$ 558.4298.

3-(dimethylamino)-2-(tetradecyloxy)propan-1-ol, 14. Alkylated alcohol 13 (358 mg, $0.642 \mathrm{mmol})$ was dissolved in a mixture of $20 \%$ TFA in DCM (2:8). The reaction was stirred for two hours at room temperature. The organic layer was carried to basic $\mathrm{pH}$ with $1 \mathrm{M} \mathrm{NaOH}$ solution and was extracted three times with dichloromethane $(20 \mathrm{~mL})$. The organic layer was dried with sodium sulphate and the solvent was evaporated. The residue was purified by flash chromatography (DCM:MeOH:TEA 90:9:1).

Yield: 76\%; IR (film) 3110, 2960, 2874, 1530, 1470, 1065, $864 \mathrm{~cm}^{-1} ;{ }^{1} \mathrm{H}-\mathrm{NMR}$ (400 $\left.\mathrm{MHz}, \mathrm{CDCl}_{3}\right) \breve{u} 3.79(\mathrm{dd}, J=10.9 \mathrm{~Hz}, 4.1 \mathrm{~Hz}, 1 \mathrm{H}), 3.68(\mathrm{~m}, 1 \mathrm{H}), 3.48(\mathrm{~m}, 5 \mathrm{H}), 2.60$ $(\mathrm{m}, 2 \mathrm{H}), 2.32(\mathrm{~s}, 6 \mathrm{H}), 1.54(\mathrm{~m}, 2 \mathrm{H}), 1.25(\mathrm{~m}, 20 \mathrm{H}), 0.88(\mathrm{t}, J=6.6 \mathrm{~Hz}, 3 \mathrm{H}) ;{ }^{13} \mathrm{C}-\mathrm{NMR}$ $\left(400 \mathrm{MHz}, \mathrm{CDCl}_{3}\right)$ ŭ 75.3, 70.1, 65.6, 62.9, 46.5, 32.1, 30.3, 29.9,29.8, 29.8, 29.8, 29.8, 29.6, 29.5, 26.3, 22.9, 14.3; HR ESI MS: $m / z$ calculated for $\mathrm{C}_{19} \mathrm{H}_{41} \mathrm{NO}_{2}\left(\mathrm{M}^{+}+\mathrm{H}\right)$, 316.2143, found $m / z 316.2142$.

2,3-bis(tetradecyloxy)propan-1-ol, 18. A mixture of protected alcohol 17 (100 mg, $0.191 \mathrm{mmol}), N, N$ - dimethylbarbituric acid $(80 \mathrm{mg}, 0.514 \mathrm{mmol}, 2.7 \mathrm{eq})$ and $\mathrm{Pd}\left[\left(\mathrm{PPh}_{3}\right)\right]_{4}$ catalyst $(12.3 \mathrm{mg}, 0.011 \mathrm{mmol}, 0.05 \mathrm{eq})$ was dissolved in anhydrous THF $(2.5 \mathrm{~mL})$ and heated at $90^{\circ} \mathrm{C}$ in a sealed-tube overnight. The solvent was evaporated and the residue was purified by flash chromatography (DCM:MeOH $0 \%$ to $1 \%$ ) to yield a white solid.

Yield: 97\%; ${ }^{1} \mathrm{H}-\mathrm{NMR}\left(400 \mathrm{MHz}, \mathrm{CDCl}_{3}\right)$ ŭ $3.72(\mathrm{~m}, 1 \mathrm{H}), 3.61(\mathrm{~m}, 2 \mathrm{H}), 3.50(\mathrm{~m}, 2 \mathrm{H})$, $3.30(\mathrm{~m}, 2 \mathrm{H}), 2.91(\mathrm{~m}, 2 \mathrm{H}), 2.15(\mathrm{~m}, 2 \mathrm{H}), 1.54(\mathrm{~m}, 8 \mathrm{H}), 1.26(\mathrm{~m}, 12 \mathrm{H}), 0.88(\mathrm{t}, J=6.88$ $\mathrm{Hz}, 6 \mathrm{H})$. 
General procedure for the synthesis of lipo-phosphoramidites 14 and 19. Diisopropylethylamine (2 eq) was added dropwise at room temperature to a solution formed by alcohol 14, or 18 (1 eq) in DCM (2 mL). Subsequently, DCM solutions were cooled at $0^{\circ} \mathrm{C}$ and b-cyanoethyl- $N, N$-diisopropylaminophosphochloride (1.0 eq) was added. The resulting reactions were removed from the ice bath and allowed to warm to room temperature, with stirring after 2 hours. The reactions were diluted with more dichloromethane $(10 \mathrm{~mL})$ and extracted with $10 \mathrm{~mL}$ of cold $0.5 \mathrm{M}$ sodium bicarbonate. The organic layers were dried with anhydrous sodium sulphate and evaporated to leave a clear colourless syrup. A vacuum pump was used to remove the last traces of solvent and diisopropylethylamine. The resulting products were used without further purification.

2-cyanoethyl 3-(dimethylamino)-2-(tetradecyloxy)propyl diisopropylphosphoramidite, 15. Yield: $69 \% ;{ }^{1} \mathrm{H}-\mathrm{NMR}\left(400 \mathrm{MHz}, \mathrm{CDCl}_{3}\right) \breve{\mathrm{u}} 4.18(\mathrm{~m}, 2 \mathrm{H}), 3.88(\mathrm{~m}, 1 \mathrm{H}), 3.56(\mathrm{~m}$, 6H), $2.76(\mathrm{~m}, 2 \mathrm{H}), 2.63(\mathrm{~m}, 2 \mathrm{H}), 2.26(\mathrm{~s}, 6 \mathrm{H}), 1.56(\mathrm{~m}, 2 \mathrm{H}), 1.25(\mathrm{~m}, 22 \mathrm{H}), 1.19(\mathrm{~m}$, $12 \mathrm{H}), 0.88(\mathrm{t}, \mathrm{J}=6.5 \mathrm{~Hz}, 3 \mathrm{H}) ;{ }^{31} \mathrm{P}-\mathrm{NMR}\left(300 \mathrm{MHz}, \mathrm{CDCl}_{3}\right)$ ŭ 150.1.

2,3-bis(tetradecyloxy)propyl 2-cyanoethyl diisopropylphosphoramidite, 19. Yield: 80\%; ${ }^{1} \mathrm{H}-\mathrm{NMR}\left(300 \mathrm{MHz}, \mathrm{CDCl}_{3}\right)$ ŭ $4.12(\mathrm{~m}, 2 \mathrm{H}), 3.79(\mathrm{~m}, 1 \mathrm{H}), 3.47(\mathrm{~m}, 8 \mathrm{H}), 3.26(\mathrm{~m}, 1 \mathrm{H})$, $2.69(\mathrm{~m}, 2 \mathrm{H}), 2.56(\mathrm{~m}, 2 \mathrm{H}), 1.48(\mathrm{~m}, 4 \mathrm{H}), 1.18(\mathrm{~m}, 44 \mathrm{H}), 1.12(\mathrm{~d}, J=6.7 \mathrm{~Hz}, 6 \mathrm{H}), 1.10$ $(\mathrm{d}, J=6.7 \mathrm{~Hz}, 6 \mathrm{H}), 0.81(\mathrm{t}, J=6.6 \mathrm{~Hz}, 6 \mathrm{H}) ;{ }^{31} \mathrm{P}-\mathrm{NMR}\left(300 \mathrm{MHz}, \mathrm{CDCl}_{3}\right)$ ŭ 150.1. Oligodeoxynucleotide synthesis. Oligodeoxynucleotide sequences were prepared using solid phase methodology. The syntheses were carried out on an Applied Biosystems Model 3400 DNA synthesizer using a $1 \varepsilon$ mol scale. Oligonucleotides were purified by reversed-phase HPLC, as described above. Mass spectrometry of modified dodecamers: 20 [5ôd(CGCGAATTCGCG)-C ${ }_{14}-3 \hat{q}$ found 3994, expected 3996; 21 [5ô d(CGCGAATTCGCG)-C 18 -3ậ: found 4045, expected 4048; $22 \quad\left[\mathrm{C}_{28}-5 \hat{\theta}\right.$ 
d(CGCGAATTCGCG)-3ẫ: found $\quad 4196$, expected $4192 ; \quad \mathbf{2 3} \quad\left[\mathrm{C}_{14} \mathrm{~N}-5 \hat{o}\right.$ d(CGCGAATTCGCG)-3ỗ: found 4028, expected 4025.

Oligoribonucleotides. The following RNA sequences were obtained from commercial sources (Sigma-Proligo, Dharmacon): passenger scrambled 5ôCAG UCG CGU UUG CGA CUG G-dT-dT-3ô guide scrambled 5ôCCA GUC GCA AAC GCG ACU G-dTdT-3ô guide anti-TNFŬ. 5ôGAG GCU GAG ACA UAG GCA C-dT-dT-3ô and passenger anti-TNFŬ. 5ôGUG CCU AUG UCU CAG CCU C-dT-dT-3ô RNA monomers in capital letters, dT represents thymidine. The 3ôcholesterol passenger antiTNFŬ. strand 5ôGUG CCU AUG UCU CAG CCU C-dT-dT-3ôcholesterol was prepared using the cholesterol-tetraethyleneglycol (TEG)-3ôCPG support from commercial sources (Glen Research).

Oligoribonucleotides were prepared on a DNA synthesizer (Applied Biosystems 3400) using 2-cyanoethyl phosphoramidites. The following solutions were used: $0.4 \mathrm{M} 1 \mathrm{H}$ tetrazol in ACN (activation); 3\% trichloroacetic acid in DCM (detritylation), acetic anhydride / pyridine / tetrahydrofurane (1: 1:8) (capping A), $10 \% \mathrm{~N}$-methylimidazole in tetrahydrofurane (capping B), 0.01 M iodine in tetrahydrofurane / pyridine / water (7: 2: 1) (oxidation). Guanosine was protected with the dimethylaminomethylidene group, cytidine was protected with the acetyl group and adenosine with the benzoyl group. The 2ôOH protecting group for the RNA monomers was the $t$-butyldimethylsilyl (TBDMS) group. The average coupling yield was around 97-98\% per step. Modified RNA strands were purified using DMT-on based protocols: RNAs were cleaved from the support with a mixture of concentrated ammonia and ethanol $3: 1$ at $55{ }^{\circ} \mathrm{C}$ for 60 minutes. The solvent was evaporated to dryness and a $1 \mathrm{M}$ solution of TBAF in THF was added. RNAs were incubated for 24 hours at room temperature. The deprotection reaction was quenched and modified RNA conjugates were desalted (Sephadex, NAP-10) and 
purified by semi-preparative HPLC. DMTr groups were then deprotected (AcOH 80\%, $30 \mathrm{~min}$ ) and extracted them with ether. Finally, chemically modified RNA conjugates were desalted (Sephadex, NAP-5).

Melting experiments on siRNA duplexes. A $100 \mathrm{mM}$ potassium acetate, $2 \mathrm{mM}$ magnesium acetate and $30 \mathrm{mM}$ HEPES-KOH solution at $\mathrm{pH}=7.4$ at a final concentration of approximately $0.25 \mathrm{OD}$ for each strand was used for the melting experiments. The solutions were heated to $90^{\circ} \mathrm{C}$ and allowed to cool slowly to room temperature. Melting curves were recorded using a concentration of approximately 1 $\mu \mathrm{M}$ for each strand in $1 \mathrm{~mL}$ of the tested solution in Teflon-stoppered quartz cuvettes of $1 \mathrm{~cm}$ optical path length. The melting temperatures were determined as the maxima of the first derivative of absorbance versus temperature. In all cases, the complexes displayed sharp, apparently two-state transitions. The data were analyzed by the denaturation curve-processing program.

Table 2

Annealing of the siRNA duplexes. Equimolar amounts of the corresponding passenger and guide strands were dissolved in a buffer containing $10 \mathrm{mM}$ TRIS $50 \mathrm{mM} \mathrm{NaCl}$ $(100 \mu \mathrm{L})$ and annealed in a final volume of $100 \mu \mathrm{L}$. The solutions of siRNAs were heated at $94^{\circ} \mathrm{C}$ for two minutes and allowed to cool until they reached room temperature. Then, $3 \mathrm{M} \mathrm{NaOAc} \mathrm{pH}=5.2$ were added $(10 \mu \mathrm{L})$ along with EtOH $(96 \%)$ $(275 \mu \mathrm{L})$. Samples were stirred, centrifuged at $4^{\circ} \mathrm{C}(15$ minutes, $12000 \mathrm{rpm})$ and precipitated at $-20^{\circ} \mathrm{C}$. Finally, the supernatant was removed and the respective pellets were carefully dried under argon.

Cell culture and siRNA conjugates treatments. PROTOCOL A (transfection of lipidsiRNA conjugates using Oligofectamine): HeLa cells were cultured under standard 
conditions $\left(37^{\circ} \mathrm{C}, 5 \% \mathrm{CO}_{2}\right.$, Dulbeccô̂ Modified Eagle Medium, $10 \%$ fetal bovine serum, $2 \mathrm{mM}$ l-glutamine, supplemented with penicillin $(100 \mathrm{U} / \mathrm{mL})$ and streptomycin (100 mg/mL). All experiments were conducted at 40ï 60\% confluence. HeLa cells were transfected with $250 \mathrm{ng}$ of murine expressing TNF-Ǔ plasmid using lipofectin (Invitrogen), according to the manufacturerô instructions. One hour after transfection,

m-TNF-Ǔ expressing HeLa cells were then transfected with unmodified siRNA-1 and modified (siRNA-2, siRNA-3, siRNA-4, siRNA-5, siRNA-6, siRNA-7, siRNA-9, or siRNA-10) and a scrambled sequence siRNA-8 at 50nM per well against TNF-Ŭusing oligofectamine (Invitrogen). The TNF-Ǔconcentration was determined from cell culture supernatant by an enzyme-linked immunoabsorbent assay kit (Bender MedSystems) following the manufacturerôs instructions.

PROTOCOL B (transfection of lipid-siRNA conjugates $s$ in the absence of Oligofectamine): HeLa cells were co-transfected with murine expressing TNF-Ǔ plasmid as in the protocol A. One hour later, lipid-siRNA conjugates (siRNA-2, siRNA3, siRNA-4, siRNA-5, siRNA-6 and siRNA-7) and a scrambled sequence siRNA-8 at 100nM were added. The TNF-Ŭ concentration was determined from cell culture supernatant by an enzyme-linked immunoabsorbent assay kit (Bender MedSystems), following the manufacturerôs instructions.

\section{REFERENCES}

[1] T. Aboul-Fadl, Curr. Med. Chem., 2005 12, 2193.

[2] J.H. Chan, S. Lim, W. S. Wong, Clin. Exp. Pharmacol. Physiol., 2006, 33, 533.

[3] C. Wilson, A.D. Keefe, Curr. Opin. Chem. Biol., 2006, 10, 607.

[4] T. Tuschl, ChemBioChem, 2001, 2, 239. 
[5] E. Uhlmann, A. Peyman, Chem. Rev., 1990, 90, 543.

[6] D. Bumcrot, M. Manoharan, V. Koteliansky, D. W. Sah, Nat. Chem. Biol., 2006, 2,711 .

[7] A. De Fougerolles, M. Manoharan, R. Meyers, R., H.P. Vornlocher, Methods Enzymol., 2005, 392, 278.

[8] M.A. Mintzer, E.E. Simanek, Chem. Rev., 2009, 109, 259.

[9] E. Urban, C.R. Noe, C. R. Farmaco, 2003 58, 243.

[10] C.X. Li, A. Parker, E. Menocal, S. Xiang, L. Borodyansky, J.H. Fruehauf, Cell Cycle, 2006, 5, 2103.

[11] T.M. Rana, Nature Rev. Mol. Cell. Biol., 2007, 8, 23.

[12] R.S. Geary, Expert Opin. Drug. Metab. Toxicol., 2009, 5, 381.

[13] P.S. Miller, Biotechnology, 1991, 9, 358.

[14] S.M. Gryaznov, Chem. Biodivers., 2010, 7, 477.

[15] R.N. Veedu, J. Wengel, Chem. Biodivers., 2010, 7, 536.

[16] P. Nielsen, Curr. Opin. Mol. Ther., 2010, 12, 184.

[17] H. de Martimprey, C. Vauthier, C. Malvy, P. Couvreur, Eur. J. Pharm. Biopharm., 2009, 3, 490.

[18] G. Godeau, C. Staedel, P. Barthélémy, J. Med. Chem., 2008, 51, 4374.

[19] F. Said Hassane, A.F. Saleh, R. Abes, M.J. Gait, B. Lebleu, Cell. Mol. Life Sci., 2010, 5,715 .

[20] N. Li, T. Larson, H.H. Nguyen, K.V. Sokolov, A.D. Ellington, Chem. Commun., 2010, 46, 392.

[21] R. Eritja, A. Pons, M. Escarceller, E. Giralt, F. Albericio, Tetrahedron, 1991, 47, 4113.

[22] Y.L. Chiu, A. Ali, C.Y. Chu, H. Cao, H., T.M. Rana, Chem. Biol., 2004, 11, 1165. 
[23] A. Detzer, M. Overhoff, W. Wünsche, M. Rompf, J.J. Turner, G.D. Ivanova, M.J. Gait, G. Sczakiel, RNA, 2009, 15, 627.

[24] S.S. Kim, C. Ye, P. Kumar, I. Chiu, S. Subramanya, H. Wu, P. Shankar, N. Manjunath, Mol. Ther., 2010, 18, 993.

[25] A. Pathak, S. Patnaik, K.C. Gupta, Biotechnol. J., 2009, 11, 1559.

[26] K.A. Whitehead, R. Langer, D.G. Anderson, Nature Rev. Drug Discov., 2009, 8, 129.

[27] J.K. Watts, D.R. Corey, Bioorg. Med. Chem. Lett., 2010, 20, 3203.

[28] A. de Fougerolles, H.P. Vornlocher, J. Maraganore, J. Lieberman, Nature Rev. Drug Discov., 2007, 6, 443.

[29] J. Soutschek, A. Akinc, B. Bramlage, K. Chavisse, R. Constien, M. Donoghue, S. Elbashir, A. Geick, P. Hadwiger, J. Harborth, M. John, V. Kesavan, G. Lavine, R.K. Pandey, T. Racie, K.G. Rajeev, I. Röhl, I. Toudjarska, G. Wang, S. Wuschko, D. Bumcrot, V. Koteliansky, S. Limmer, M. Manoharan, H.P. Vornlocher, Nature, 2004, $432,173$.

[30] C. Lorenz, P. Hadwiger, M. John, H.P. Vornlocher, C. Unverzagt, Bioorg. Med. Chem. Lett., 2004, 14, 4975.

[31] Y. Ueno, K. Kawada, T. Naito, A. Shibata, K. Yoshikawa, H.S. Kim, Y. Wataya, Y. Kitade, Bioorg. Med. Chem., 2008, 16, 7698.

[32] C. Wolfrum, S. Shi, K.N. Jayaprakash, M. Jayaraman, G. Wang, R.K. Pandey, K.G. Rajeev, T. Nakayama, K. Charisse, E.M. Ndungo, T. Zimmermann, V. Koteliansky, M. Manoharan, M. Stoffel, Nature Biotechnol., 2007, 25, 1149.

[33] A. Aviñó, S.M. Ocampo, C. Caminal, J.C. Perales, R. Eritja, Mol. Divers., 2009, $13,287$. 
[34] S. Grijalvo, M. Terrazas, A. Aviñó, R. Eritja, Bioorg. Med. Chem. Lett., 2010, 20, 2144.

[35] A.D. Judge, V. Sood, J.R. Shaw, D. Fang, K. McClintock, I. MacLachlan, Nature Biotechnol., 2005, 23, 457.

[36] J. Heyes, L. Palmer, K. Bremner, I. MacLachlan, J. Contr. Rel., 2005, 107, 276.

[37] T.S. Zimmermann, A.C. Lee, A. Akinc, B. Bramlage, D. Bumcrot, M.N. Fedoruk, J. Harborth, J.A. Heyes, L.B. Jeffs, M. John, A.D. Judge, K. Lam, K. McClintock, L.V. Nechev, L.R. Palmer, T. Racie, I. Röhl, S. Seiffert, S. Dhanmugam, V. Sood, J. Soutschek, I. Toudjarska, A.J. Wheat, E. Yaworski, W. Zedallis, V. Koteliansky, M. Manoharan, H.P. Vornlocher, I. MacLachlan, Nature, 2006, 441, 111.

[38] T.W. Geisberg, L.E. Hensley, E. Kagan, E.Z. Yu, J.B. Geisberg, K. DaddanoDiCaprio, E.A. Fritz, P.B. Jahrling, K. McClintock, J.R. Phelps, A.C. Lee, A. Judge, L.B. Jeffs, I. MacLachlan, J. Infect. Dis., 2006, 193, 1650.

[39] A. Rait, K. Pirollo, D.W. Will, A. Peyman, W.Rait, E. Uhlmann, E.H. Chang, Bioconjugate Chem., 2000, 11, 153.

[40] R.T. Pon, in áMethods in Molecular Biology Vol. 20: Protocols for Oligonucleotides and Analogsô Ed. S. Agrawal, Humana Press Inc., Totowa, New Jersey, 1993, p. 465.

[41] K.C. Gupta, P. Kumar, D. Bhatia, A.K. Sharma, Nucleosides, Nucleotides, 1995, 14,829 .

[42] R.A. Moss, W. Jiang, Langmuir, 1995, 11, 4217.

[43] D.R. Sorensen, M. Leirdal, M. Sioud, J. Mol. Biol., 2003, 327, 761.

[44] M. Manoharan, Biochim. Biophys. Acta, 1999, 1489, 117; E. Rozners, J. Moulder, Nucleic Acids Res., 2004, 32, 248. 


\section{LEGENDS}

Scheme 1. Synthesis of lipid-functionalized CPG solid supports $\mathbf{5}$ and $\mathbf{1 0}$ used for the preparation of DNA/RNA molecules carrying lipids at the 3ôposition. Reagents and Conditions: (a) $\mathrm{NaH}$ (60\%), 1-Bromotetradecane or 6, toluene, reflux, overnight, 2 (78\%), 7 (77\%); (b) p TsOH, MeOH, r.t., overnight, 3 (72\%), 8 (70\%); (c) MMTr-Cl, DMAP, pyridine, $40^{\circ} \mathrm{C}$, overnight, 4 (80\%), 9 (67\%); (d) CPG derivatization.

Scheme 2. Synthesis of lipophosphoramidites $\mathbf{1 5}$ and $\mathbf{1 9}$ to be introduced into DNA/RNA molecules at the 5ôposition. Reagents and Conditions: For lipophosphoramidite 15: (a) Trityl chloride (reference 42); (b) $\mathrm{NaH}$ (60\%), THF, reflux, overnight; 76\%; (c) DCM:TFA 20\%, r.t., 2 h, 76\%; (d) $\mathrm{NC}\left(\mathrm{CH}_{2}\right)_{2} \mathrm{OP}\left(\mathrm{iPr}_{2} \mathrm{~N}\right) \mathrm{Cl}$, DIEA, DCM, $0^{\circ} \mathrm{C}$ to r.t., $1 \mathrm{~h} 30 \mathrm{~min}$. For lipophosphoramidite 19: (a) 1-bromotetradecane (reference 36); (b) $\mathrm{Pd}\left[\left(\mathrm{PPh}_{3}\right)\right]_{4}, N, N$ - dimethylbarbituric acid, THF, $90^{\circ} \mathrm{C}$, sealed tube, overnight, $97 \%$; (c) $\mathrm{NC}\left(\mathrm{CH}_{2}\right)_{2} \mathrm{OP}\left(\mathrm{iPr}_{2} \mathrm{~N}\right) \mathrm{Cl}$, DIEA, DCM, $0^{\circ} \mathrm{C}$ to r.t., $1 \mathrm{~h} 30 \mathrm{~min}$

Figure 1. Proposed lipid modifications to be introduced into DNA and RNA molecules. (a) Selected lipids were introduced at the 3ôtermini and (b) selected lipids were introduced at the 5ôtermini.

Figure 2. Plot of gene-specific silencing activities for unmodified (siRNA-1), modified (siRNA-2, siRNA-3, siRNA-4, siRNA-5, siRNA-6, siRNA-7 and siRNA-8) conjugates along with a scrambled sequence Scr (50 nM per well). Transfection of siRNA conjugates was carried out using Oligofectamine (Protocol A). Values are represented 
as the average $\pm E S, n=3$ and are compared to a scrambled sequence. $* * * p<0.001$, ANOVA Test, Bonferrini post-test.

Figure 3. Plot of gene-specific silencing activities for unmodified (siRNA-1) and modified (siRNA-2, siRNA-3, siRNA-4, siRNA-5, siRNA-6 and siRNA-7) lipid-siRNA conjugates along with a scrambled sequence siRNA-8 at $100 \mathrm{nM}$ without transfecting agent (Protocol B).

Figure 4. Plot of gene-specific silencing activities for unmodified (siRNA-1) and modified (siRNA-9 and siRNA-10) lipid-siRNA conjugates along with a scrambled siRNA-8 at $50 \mathrm{nM}$ with transfecting agent (Protocol A). 
Table 1. Modified and Unmodified RNA Sequences Used for the Preparation of the Corresponding siRNA Conjugates for RNA Interference Studies.

\begin{tabular}{|c|c|c|c|c|}
\hline $\begin{array}{l}\text { Compound } \\
\text { number }\end{array}$ & $\operatorname{Lipid}^{\mathrm{a}}$ & Sequence $\left(5 \hat{o} 3 \hat{o}^{b}\right.$ & $\mathrm{MS}^{\mathrm{c}}$ & $\operatorname{siRNA}^{d}$ \\
\hline 24 & $\begin{array}{l}\text { None } \\
\mathrm{P}, \mathrm{wt}\end{array}$ & $\begin{array}{c}\text { GUG CCU AUG UCU CAG CCU } \\
\text { C-dT-dT }\end{array}$ & n. d. & siRNA-1 \\
\hline 25 & $\mathrm{Chol}^{\mathrm{e}, \mathrm{P}}$ & $\begin{array}{c}\text { GUG CCU AUG UCU CAG CCU } \\
\text { C-dT-dT-Chol }\end{array}$ & $\begin{array}{l}7319 / \\
7310\end{array}$ & siRNA-2 \\
\hline 26 & $\begin{array}{c}\mathrm{C}_{14-3 \mathrm{Q}} \\
\mathrm{P}\end{array}$ & $\begin{array}{c}\text { GUG CCU AUG UCU CAG CCU } \\
\qquad \text { C-dT-dT-C } 14\end{array}$ & $\begin{array}{l}6909 / \\
6908\end{array}$ & siRNA-3 \\
\hline 27 & $\begin{array}{c}\mathrm{C}_{14-30} \\
\mathrm{P}\end{array}$ & $\begin{array}{c}\text { GUG CECU AUG } \underline{\text { UCU }} \underline{\mathrm{C} A G} \underline{\mathrm{CC}} \underline{\mathrm{U}} \\
\text { C-dT-dT-C } 14\end{array}$ & $\begin{array}{c}7013 \\
{\left[\mathrm{M}+\mathrm{Na}^{+}\right] /} \\
6993\end{array}$ & siRNA-4 \\
\hline 28 & $\begin{array}{c}\mathrm{C}_{18}-3 \hat{\mathrm{Q}} \\
\mathrm{P}\end{array}$ & $\begin{array}{c}\text { GUG CCU AUG UCU CAG CCU } \\
\text { C-dT-dT-C } 18\end{array}$ & $\begin{array}{l}6964 / \\
6961\end{array}$ & siRNA-5 \\
\hline 29 & $\begin{array}{c}\mathrm{C}_{14} \mathrm{~N}-5 \hat{O} \\
\mathrm{P}\end{array}$ & $\begin{array}{c}\mathrm{C}_{14} \mathrm{~N}-\mathrm{GUG} \text { CCU AUG UCU CAG } \\
\text { CCU C-dT-dT }\end{array}$ & $\begin{array}{l}6934 / \\
6937\end{array}$ & siRNA-6 \\
\hline 30 & $\begin{array}{c}\mathrm{C}_{28} \mathrm{~N}-5 \hat{O} \\
\mathrm{P}\end{array}$ & $\begin{array}{c}\mathrm{C}_{28} \text {-GUG CCU AUG UCU CAG } \\
\text { CCU C-dT-dT }\end{array}$ & $\begin{array}{l}7112 / \\
7106\end{array}$ & siRNA-7 \\
\hline 31 & $\begin{array}{l}\text { None } \\
\mathrm{P}, \mathrm{scr}\end{array}$ & $\begin{array}{c}\text { CAG UCG CGU UUG CGA CUG } \\
\text { G-dT-dT }\end{array}$ & n. d. & siRNA-8 \\
\hline 32 & $\begin{array}{c}\mathrm{C}_{14-3 \hat{Q}} \\
\mathrm{G}\end{array}$ & $\begin{array}{c}\text { GAG GCU GAG ACA UAG GCA } \\
\text { C-dT-dT-C } 14\end{array}$ & $\begin{array}{l}7123 / \\
7120\end{array}$ & siRNA-9 \\
\hline 33 & $\begin{array}{c}\mathrm{C}_{18}-3 \hat{Q} \\
\mathrm{G}\end{array}$ & $\begin{array}{c}\text { GAG GCU GAG ACA UAG GCA } \\
\text { C-dT-dT-C } 18\end{array}$ & $\begin{array}{l}7176 / \\
7174\end{array}$ & $\begin{array}{l}\text { siRNA- } \\
\mathbf{1 0}\end{array}$ \\
\hline
\end{tabular}


${ }^{\mathrm{a}} \mathrm{wt}$ : wild type, P: passenger strand, G: guide strand, scr: scrambled, ${ }^{\mathrm{b}} \mathrm{RNA}$ monomers are in uppercase letters, dT stands for thymidine. ${ }^{\mathrm{c}}$ Mass spectra (found / expected). ${ }^{d}$ siRNA were prepared by hybridization with the corresponding guide strands (24-30 with 5ôGAG GCU GAG ACA UAG GCA C-dT-dT-3ô 31 with 5ôCCA GUC GCA AAC GCG ACU G-dT-dT-3ôand 32 and 33 with 5ôGUG CCU AUG UCU CAG CCU

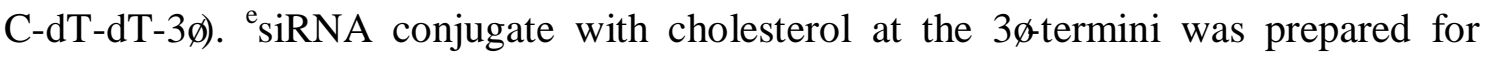
comparison purposes. ${ }^{\mathrm{f}} \mathrm{RNA}$ with underline contains $2 \hat{o} \mathrm{O}$-methyl-RNA monomers. n.d. not determined. 
Table 2. Melting Temperatures $\left({ }^{\circ} \mathrm{C}\right)$ of the siRNA Conjugates Prepared in this Study. ${ }^{a}$

\begin{tabular}{|c|c|c|}
\hline siRNA & Lipid & $\mathrm{T}_{\mathrm{m}}\left(\Delta \mathrm{T}_{\mathrm{m}}{ }^{\mathrm{b}}\right)$ \\
\hline siRNA-1 & None & 83.5 \\
\hline siRNA-3 & $\mathrm{C}_{14-30}$ & $83.9(0.4)$ \\
\hline siRNA-4 & $\mathrm{C}_{14}$-30̂ & $86.9(3.4)$ \\
\hline siRNA-5 & $\mathrm{C}_{18}-30 \hat{0}$ & $83.6(0.1)$ \\
\hline siRNA-6 & $\mathrm{C}_{28}$-5ô & $84.3(0.8)$ \\
\hline
\end{tabular}

${ }^{\mathrm{a}}$ Conditions: $100 \mathrm{mM}$ potassium acetate, $2 \mathrm{mM}$ magnesium acetate and $30 \mathrm{mM}$ HEPES$\mathrm{KOH}$ solution at $\mathrm{pH}$ 7.4. ${ }^{\mathrm{b}} \Delta \mathrm{T}_{\mathrm{m}}$ is the difference between the melting temperature of the lipid siRNA minus the melting temperature of the corresponding unmodified siRNA. 
Scheme 1

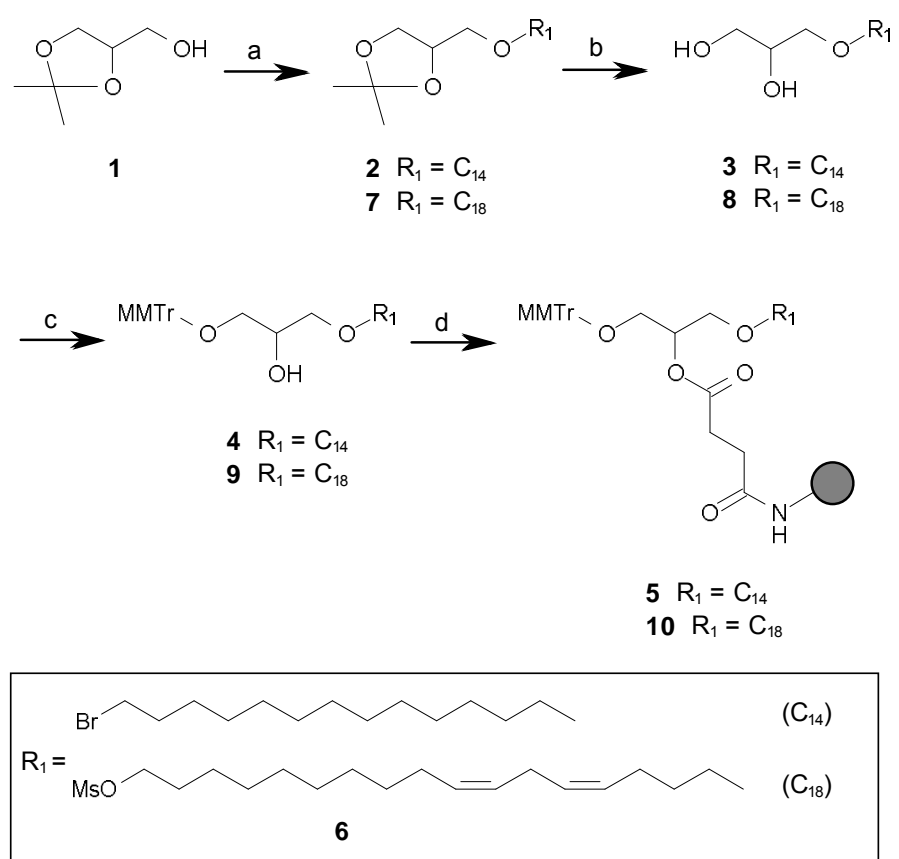


Scheme 2

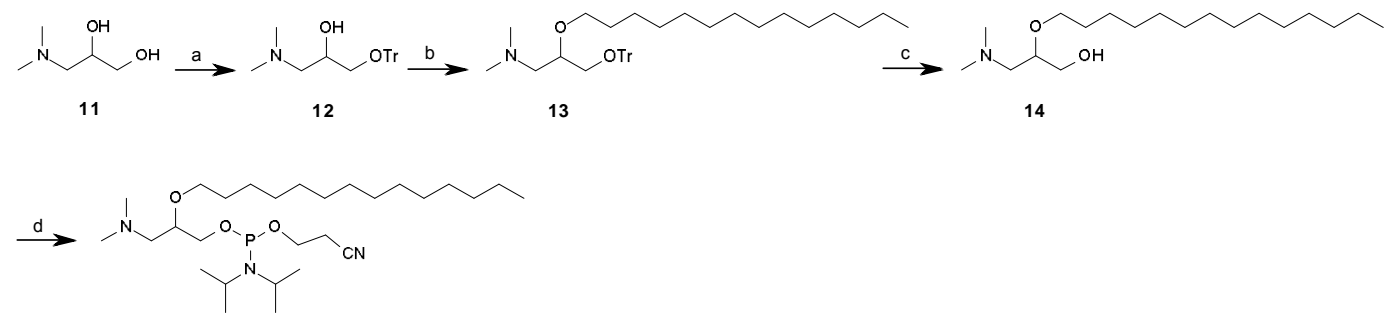

15
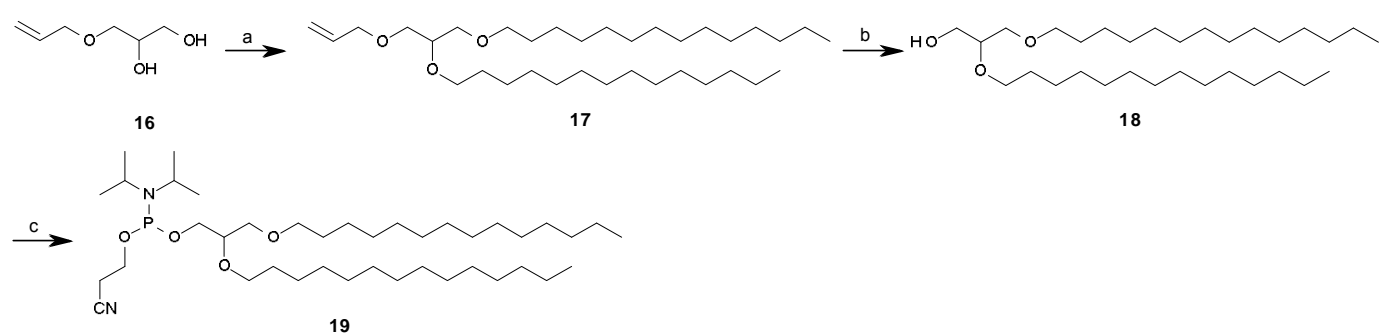
Figure 1

(a) General structure for DNA/RNA molecules at 3'-positions
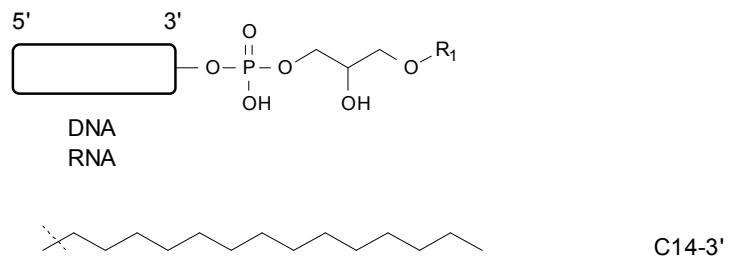

$\mathrm{R}_{1}=$

where

C18-3'

(b) General structure for DNA/RNA molecules at 5'-positions

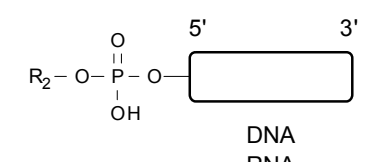

RNA

where
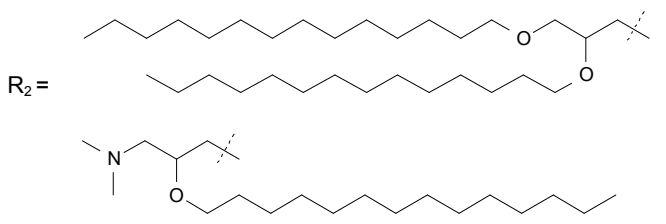

C14N-5' 
Figure 2

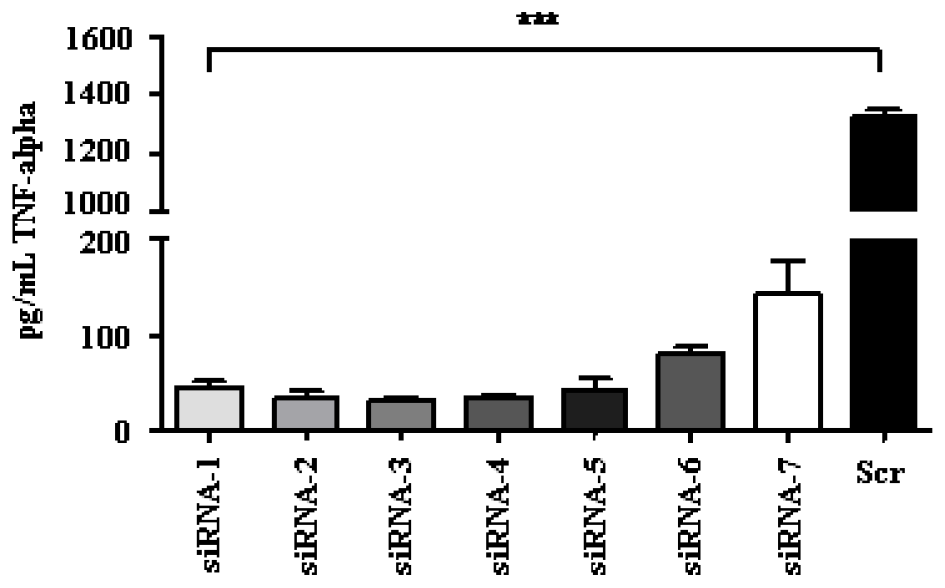


Figure 3

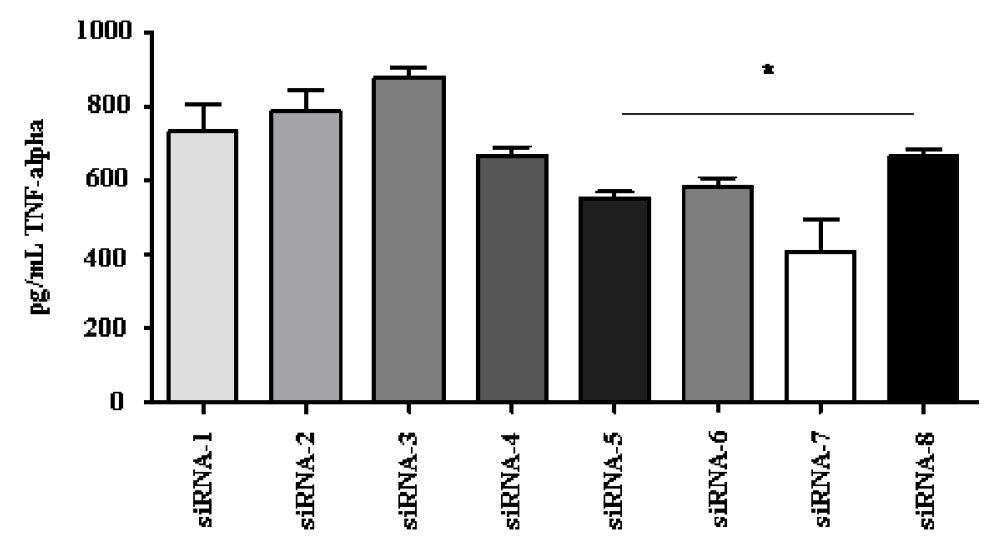


Figure 4

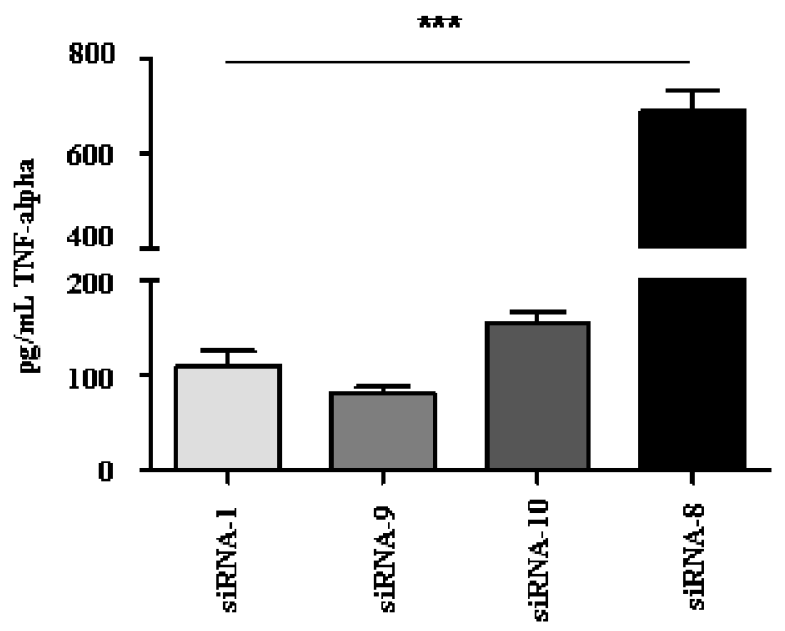


Graphical illustration for the table of contents

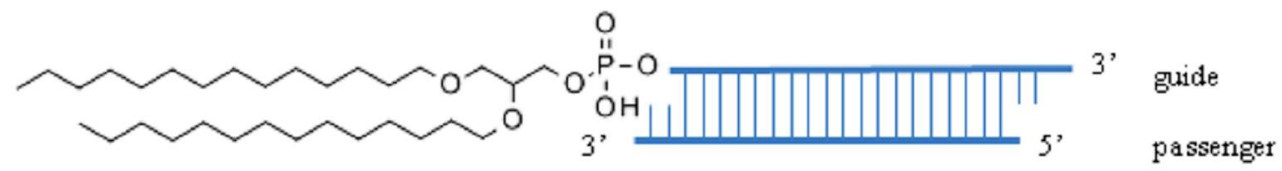

